\title{
Effectiveness of Plant Extracts as Safe Control Means against Damping-off and Root Rot Diseases in Faba Bean Plants M.F. Abdel-Monaim, M.M. Mazen and Marwa
}

A.M. Atwa

Plant Pathol. Res. Inst., Agric. Res. Centre, Giza, Egypt.

$\mathbf{F}$

aba bean root rot caused by Fusarium solani and Rhizoctonia solani is one of the most important biotic stresses in the major growing areas in Egypt. In this study, aqueous extracts and organic solvent extracts of three wild medicinal plants (Lawsonia inermis, Eugenia jambolana and Moringa oleifera) were evaluated in vitro and in vivo for protection of faba bean plants against damping-off and root rot diseases. Under laboratory conditions, all aqueous and organic solvent extracts significantly suppressed linear growth of $F$. solani and $R$. solani. E. jambolana extracts recorded the highest inhibition to the linear growth of both pathogenic tested fungi. Also, organic solvent extracts were more active than aqueous extracts of all tested plants. Under greenhouse and field conditions, all tested extracts significantly reduced damping-off and root rot incidence as well as increased some crop parameters in the field compared with untreated control. Faba bean seeds treated with $E$. jambolana extracts gave the highest protection against damping-off and root rot as well as recorded the highest crop components compared to the other extracts. In physiological studies, activity of defense-related enzymes, including peroxidase (PO), polyphenoloxidase (PPO), phenylalanine ammonia lyase (PAL), superoxide dismutase (SOD) and catalase (CAT), as well as content of phenolic compounds were increased in plants treated with aqueous or organic solvent extracts grown in soil infested with any of $F$. solani and $R$. solani, compared with untreated plants (control). In general, $E$. jambolana extracts recorded the highest increase in the activity of all enzymes as well as the content of total phenolic compounds. The organic solvent extracts increased the activity of all assessed enzymes and total phenolic compounds more than aqueous extracts of all tested plants. These results suggested that aqueous and organic solvent extracts may play an important role for controlling faba bean damping-off and root rot diseases.

Keywords: Crop parameters, damping-off, faba bean, oxidative enzymes, plant extracts, and total phenolic compounds.

Faba beans are among the oldest crops in the world. The Chinese used them for food almost 5,000 years ago; they were cultivated by the Egyptians 3,000 years ago and a little later by the Greeks and Romans. Today, faba bean is a major crop in many countries including China, Ethiopia and Egypt and is widely grown for human food throughout the Mediterranean region and in parts of Latin America (Singh et al., 2013). Moreover, faba bean is the most important leguminous crop used for human nutrition in Egypt and is an excellent source of protein, calcium, phosphorus, lysine, methionine, cystein, crabohydrates, dietary fibers, choline, lecithin, and 
minerals (Wang et al., 2014). However, there are many soil-borne fungi which are able to attack faba bean plants in different growth stages causing damping-off, root rot, collar rot and wilt diseases. Soil borne fungal pathogens, i.e. F. solani and $R$. solani are considered the most important pathogens that cause serious diseases, i.e. damping-off and root-rot diseases, which affect crop productivity by reducing both quality and quantity of the yield (Abdel-Monaim, 2013). There are many methods which are presently being used to control various plant pathogens including root rot pathogens such as physical, chemical, biological, cultural etc., but to some extent effective control of plant diseases is generally achieved by the use of fungicides. Due to increased awareness about the risks involved in the use of pesticides, much attention is being focused on the alternative methods of pathogen control. The recurrent and indiscriminate use of fungicides have posed a serious threat to human health and to the existing human ecogeographical conditions as some of them have already proved to be either mutagenic, carcinogenic or tetretogenic (Sadda and Varma, 2015). Moreover, the spiralling up cost of chemical fungicides particularly in the countries, where pesticides are imported; pollution to soil, ground water and air by the accumulation of obnoxious chemicals residues due to continuous use of fungicides. in addition, development of resistance races to these chemicals are therefore now facing the scientists to look for methods which are ecologically, friendly, safe and specific for pathogens (Joseph et al., 2008).

Using of some plant products in plant disease control seems to be an effective method to control many plant diseases. Aqueous and organic solvent extracts of several plants showed inhibitory effects against the cause of damping-off and root rot diseases in vitro and in vivo (Abded-Monaim et al., 2011). Plant extracts are considered as a mixture of various compounds that have the ability to induce systemic resistance (ISR) (Kagale et al., 2011). To date, extracts of at least few plant species have been reported to contain allelopathic substances that can act as elicitors and induce systemic resistance in host plants resulting in reduction or inhibition of disease development. Also, induce accumulations of pathogenesis related proteins (PR-proteins) in many plants (Kagale et al., 2011). Treatment of some plants with plant extracts provided a control of many fungal diseases through metabolic changes in plants including induction of phenol biosynthesis enzymes, antioxidant defensive enzymes and phenol accumulation (Kagale et al., 2004; Guleria and Kumar, 2006 and Aboellil, 2007).

The present investigation aims to evaluate the effectiveness of certain plant extracts against the fungal growth in vitro and suppression of damping-off and root rot diseases of faba bean under greenhouse and field conditions. Also, investigate the effect of these treatments on some crop parameters and protein content in faba bean seeds under field conditions. The work was expanded to evaluate the activity of oxidative reductive enzymes and accumulation of phenolic compounds in faba bean plants.

Egypt. J. Phytopathol., Vol. 45, No. 1 (2017) 


\section{Materials and Methods}

Source of faba bean seeds and growth of plants:

Seeds of Faba bean (Vicia fabae L.) cultivar Misr 1 used in this study were obtained from Legume Crop Res. Dep., Field Crop Res. Inst., Agric. Res. Center, Ministry of Agric. and Land Reclamation, Egypt. Seeds were planted in plastic pots $(30 \mathrm{~cm}$ in diameter), filled with a pasteurized mixture of soil and sand $(4: 1 \mathrm{w} / \mathrm{w})$. Five seeds were sown in each pot and these pots were irrigated every three days.

Source of fungal pathogens:

Pathogenic isolates of Fusarium solani Snyder \& Hansen and Rhizoctonia solani Kühn isolated from diseased faba bean plants collected from New Valley governorate were used in this study (Abdel-Monaim, 2013). The fungi were identified on the basis of cultural properties and microscopic morphological characters according to Sneh et al. (1991) and Leslie and Summerell (2006). Subcultures of the obtained isolates were kept in PDA slants and stored at $5 \pm 1{ }^{\circ} \mathrm{C}$ for further studies.

\section{Preparation of fungal inoculum}

The inocula of $F$. solani and $R$. solani isolates were prepared from one-week old culture grown on $50 \mathrm{ml}$ potato dextrose broth (PDB) medium in conical flasks (250 $\mathrm{ml}$ ) and incubated at $25 \pm 1{ }^{\circ} \mathrm{C}$. The content of each flask was homogenized in a blender for one min. Plastic pots were filled with pasteurized soil and mixed with the fungal inoculum at the rate of $100 \mathrm{ml}$ homogenized culture per pot, seven days before sowing (Abdel-Monaim, 2013).

\section{Preparation of plant extracts:}

A. Aqueous plant extracts:

Plants belonging to three species in Table 1, were collected from different localities in El-Kharga, New Valley governorate. The selected leaves of different plants were cut into small pieces and washed several times with running tap water, then washed with sterile water and dried at room temperature $\left(\approx 25^{\circ} \mathrm{C}\right)$ for 15 days. Plant materials were ground to fine powders in a grinder, then $100 \mathrm{~g}$ of each one were blended in $1 \mathrm{~L}$ of distilled water for $48 \mathrm{~h}$. The macerated materials were squeezed through double cheesecloth sheets and then filtered through a Whitman No. 1 filter paper. The fresh extracts were applied just after preparation at the rate of $20 \%$ from the original ones (Abdel-Monaim et al., 2011).

Table 1. English name, family and scientific name of the tested plants

\begin{tabular}{|c|c|c|}
\hline English name & Family name & \multicolumn{1}{|c|}{ Scientific name } \\
\hline Henna & Lythraceae & Lawsonia inermis \\
\hline \multirow{3}{*}{ Stopper } & & Eugenia jambolana (Syn. Syzygium \\
& Myrtaceae & $\begin{array}{l}\text { cumini or Syzygium jambolana or } \\
\text { Eugenia cuminii) }\end{array}$ \\
\hline Moringa & Moringaceae & Moringa oleifera \\
\hline
\end{tabular}


B. Solvents of plant extracts:

In this experiment, some organic solvents, i.e. ether, ethanol and acetone were used for preparation of plant extracts. The method was the same to the aqueous plant extracts except using organic solvents instead of distilled water. The extracted materials with each of the solvents were concentrated with rotary vacuum evaporator at $50^{\circ} \mathrm{C}$ for $6 \mathrm{hrs}$. The final concentration was prepared as those of water extracts (20\%) by adding water for each organic solvent extract (Abdel-Monaim et al., 2011).

Evaluation of plant extracts:

A. In vitro antifungal activity:

Ten milliliters of aqueous and/or organic solvent extract prepared from any of the plant samples were mixed with $40 \mathrm{ml}$ PDA medium (20\%), poured into sterilized Petri plates at $15 \mathrm{ml} /$ plate and allowed to solidification. The plates were then inoculated with disk (9-mm in diameter) of 10-day old culture of any of $F$. solani and $R$. solani grown on PDA and incubated at $25 \pm 1{ }^{\circ} \mathrm{C}$. The percentage of radial growth inhibition of the pathogen was calculated. Each treatment was replicated three times with five plates per replicate. The mycelial growth inhibition (\%) of colony diameter grown on each extract was calculated as follows:

$$
\text { Mycelial growth inhibition }(\%)=100(\mathrm{C}-\mathrm{T} / \mathrm{C})
$$

Where, $\mathrm{C}=$ growth in control and $\mathrm{T}=$ growth in treatment.

\section{B. Under greenhouse conditions:}

The fungal inocula of $F$. solani and $R$. solani were prepared as described before. Plastic pots (30 cm diameter) were packed with pasteurized sandy clay soil infested with fungal inocula at the rate of $100 \mathrm{ml}$ homogenized culture per pot, seven days before planting. Disinfested faba bean seeds (cv. Misr 1) were soaked in the solution of each extract (aqueous or organic solvent extracts) for 12h (Somda et al., 2007), then sown in infested soil at the rate of 5 seeds/pot. While in control treatment, faba bean seeds soaked in water for the same time were sown in infested soil with the pathogen at the same rate. Four pots were used per treatment as replicates. Percentage of damping-off was recorded 30 days after planting. Moreover, severity of root rot was determined 90 days after planting using a rating scale of 0 to 5 on the basis of root discoloration or leaf yellowing as follows: 0 , neither root discoloration nor leaf yellowing; $1=$ from $<0$ to $25 \%$ root discoloration or one leaf yellowed; $2=$ from $<25$ to $50 \%$ root discoloration or more than one leaf yellowed; $3=$ from $<50$ to $75 \%$ root discoloration plus one leaf wilted; $4=$ up to $75 \%$ root discoloration or more than one leaf wilted; and 5, completely dead plants. For each replicate, a disease severity index (DSI) similar to that suggested by Liu et al. (1995) was followed:

$$
\mathrm{DS}=\Sigma \mathrm{d} /(\mathrm{d} \max \times \mathrm{n}) \times 100
$$

Whereas: $\mathrm{d}$ is the disease rating possible, $\mathrm{d}$ max is the maximum disease rating and $\mathrm{n}$ is the total number of plants examined in each replicate. 


\section{Under field conditions:}

This experiment was carried out in the Farm of El-Kharga Agric. Station, New Valley governorate during growing seasons of 2014/15 and 2015/16. The effect of water, ether, ethanol and acetone extracts of L. inermis, E. jambolana and $M$. oleifera leaves on incidence of damping-off and root rot diseases of faba bean was evaluated under natural infection as well as their effect on growth and some crop parameters under field conditions. Healthy faba bean (cv. Misr 1) seeds were soaked in the solutions of the selected extracts for $12 \mathrm{~h}$ at the rate of $20 \%$ (Somda et al., 2007). All treatments were arranged in a complete randomized block design with three plots as replicates. A plot was $3 \times 3.5 \mathrm{~m}$ with five rows; seeds were sown in hills $25 \mathrm{~cm}$ apart on both sides of the row ridge, with two seeds per hill. In the control treatment, faba bean seeds were soaked in water for the same time and sown with the same method. Percentages of damping-off and root rot disease index severity were calculated as well as some crop parameters, i.e. plant height $(\mathrm{cm})$, number of branches, pods and seeds plant ${ }^{-1}$, weight of 100 seeds (seed index) and total yield per feddan were recorded. Total crude protein (\%) in faba bean seeds was determined. The previously determined nitrogen of dry seeds was used for calculating total crude protein by multiplying N-values by 6.25 (Anonymous, 2000).

\section{Biochemical changes in faba bean plants due to plant extract treatments}

After 15 days from planting, $1 \mathrm{~g}$ fresh samples were taken from treated and untreated faba bean plants grown in soil infested and un-infested with $F$. solani and $R$. solani individually then extracted according to Maxwell and Bateman (1967). Then the extracts were used for assaying biochemical changes associated with the tested treatments of plant extracts, the activities of peroxidase enzyme (Hammerschmidt et al., 1982), polyphenoloxidase enzyme (Gauillard et al., 1993), phenylalanine ammonia lyase enzyme (Cavalcanti et al., 2007), superoxide dismutase (Dhindsa et al., 1981) and catalase (Aebi, 1984) were determined.

\section{Protein content:}

Total protein content of the samples was quantified according to the method described by Bradford (1976).

Determination of phenolic compounds:

To assess phenolic content, $1 \mathrm{~g}$ fresh plant sample was homogenized in $10 \mathrm{ml}$ $80 \%$ methanol and agitated for $15 \mathrm{~min}$. at $70^{\circ} \mathrm{C}$. One $\mathrm{ml}$ of the extract was added to $5 \mathrm{ml}$ of distilled water and $250 \mu \mathrm{l}$ of $1 \mathrm{~N}$ Folin-Ciocalteau reagent and the solution was kept at $25^{\circ} \mathrm{C}$. The absorbance was measured with a spectrophotometer at 725 $\mathrm{nm}$. Catechol was used as a standard. The amount of phenolic content was expressed as phenol equivalents in $\mu \mathrm{g} / \mathrm{gm}$ fresh tissue (Saikia et al., 2006).

\section{Statistical analysis:}

All experiments were performed twice. Analyses of variance were carried out using MSTAT-C program version 2.10 (Anonymous, 1991). Least significant difference (LSD) was employed to test for significant difference between treatments at $\mathrm{P} \leq 0.05$ (Gomez and Gomez, 1984). 


\section{R e s u l t s}

In vitro antifungal activity:

The obtained results show that all the tested extracts suppressed growth of $F$. solani (Fig. 1) and R. solani (Fig. 2) with different percentages. E. jambolana extracts gave the highest inhibition percentage for both fungi more than $L$. inermis and $M$. oleifera extracts. On the other hand, the organic solvent extracts of all tested plants highly suppressed both the pathogenic fungi more than aqueous extracts. Acetone extract recorded the highest inhibition of radial growth of both tested pathogenic fungi.

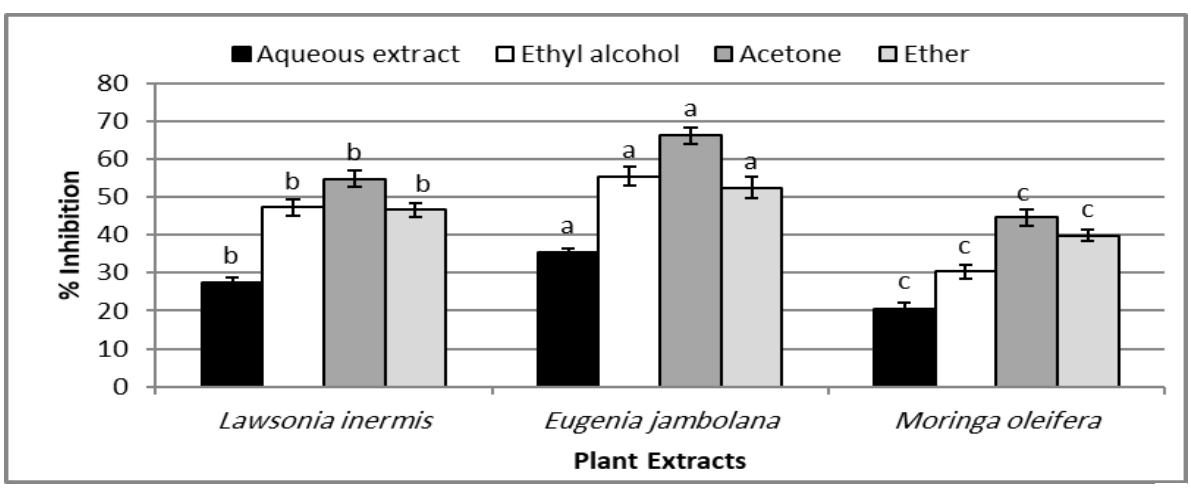

Fig. 1. In vitro effect of aqueous and organic solvent extracts of $L$. inermis, $E$. jambolana and $M$. oleifera individually on $F$. solani growth. Different letters indicate significant differences among treatments within the same color column according to the least significant difference test $(\mathrm{P} \leq$ 0.05). Bars indicate the standard deviation.

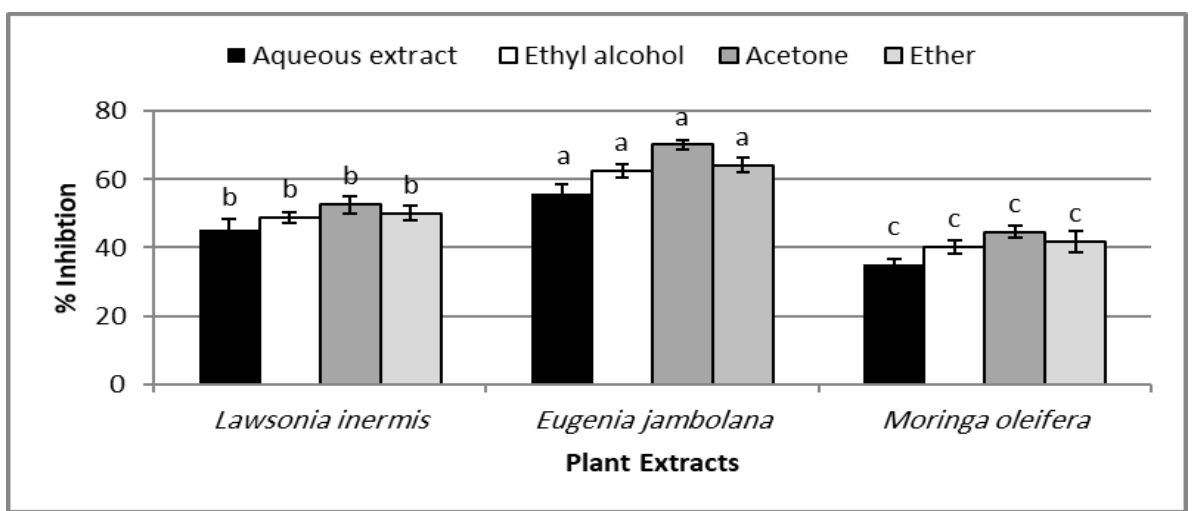

Fig. 2. In vitro effect of aqueous and organic solvent extracts of $L$. inermis, $E$. jambolana and $M$. oleifera individually on Rhizoctonia solani growth. Different letters indicate significant differences among treatments within the same color column according to the least significant difference test $(\mathrm{P} \leq \mathbf{0 . 0 5})$. Bars indicate the standard deviation. 
Greenhouse experiment:

The efficacy of aqueous and organic solvent extracts of L. inermis, E. jambolana, $M$. oleifera against damping-off and root rot diseases caused by $F$. solani and $R$. solani of faba bean is shown in Table (2). Faba bean seeds treated with any the tested plant extracts recorded significant reduction of damping-off and root rot incidence caused by the two tested fungi compared with untreated seeds (control) in pots. The extracts of $E$. jambolana recorded the highest reduction in both damping-off and root rot diseases caused by any of the tested fungi followed by $L$. inermis extract. Meanwhile, M. oleifera extract recorded the lowest protection against damping-off and root rot incidence in this respect. On the other hand, the organic solvent extracts of all tested plants suppressed damping-off and root rot incidence more than aqueous extracts. Acetone and ether extracts of all tested plants were more effective for suppressing damping-off and root rot incidence than aqueous and Ethanol extracts.

Table 2. Effect of seed soaking in aqueous and organic solvent plant extracts of $L$. inermis, $E$. jambolana and $M$. oleifera individually on the incidence of faba bean damping-off and root rot diseases caused by $F$. solani and $R$. solani under greenhouse conditions

\begin{tabular}{|c|c|c|c|c|c|}
\hline \multirow{2}{*}{$\begin{array}{c}\text { Source of } \\
\text { plant extract }\end{array}$} & \multirow[b]{2}{*}{ Solvent type } & \multicolumn{2}{|c|}{ F. solani } & \multicolumn{2}{|c|}{ R. solani } \\
\hline & & $\begin{array}{c}\% \\
\text { Damping-off }\end{array}$ & $\begin{array}{c}\% \\
\text { Root rot }\end{array}$ & $\begin{array}{c}\% \\
\text { Damping-off }\end{array}$ & $\begin{array}{c}\% \\
\text { Root rot }\end{array}$ \\
\hline \multirow{5}{*}{ L. inermis } & Aqueous extract & 20.0 & 23.75 & 25.0 & 15.75 \\
\hline & Ethanol & 20.0 & 18.75 & 15.0 & 11.25 \\
\hline & Acetone & 10.0 & 12.25 & 10.0 & 6.25 \\
\hline & Ether & 15.0 & 14.25 & 10.0 & 8.75 \\
\hline & Mean & 16.3 & 17.25 & 15.0 & 10.50 \\
\hline \multirow{5}{*}{ E. jambolana } & Aqueous extract & 15.0 & 18.25 & 15.0 & 10.00 \\
\hline & Ethanol & 10.0 & 14.25 & 10.0 & 7.25 \\
\hline & Acetone & 5.0 & 5.75 & 5.0 & 4.00 \\
\hline & Ether & 5.0 & 10.75 & 10.0 & 5.00 \\
\hline & Mean & 8.8 & 12.25 & 10.0 & 6.56 \\
\hline \multirow{5}{*}{ M. oleifera } & Aqueous extract & 25.0 & 27.25 & 30.0 & 17.75 \\
\hline & Ethanol & 20.0 & 24.25 & 20.0 & 12.25 \\
\hline & Acetone & 15.0 & 13.75 & 10.0 & 6.75 \\
\hline & Ether & 20.0 & 17.00 & 10.0 & 8.25 \\
\hline & Mean & 20.0 & 20.56 & 17.5 & 11.25 \\
\hline \multicolumn{2}{|l|}{ Control } & 45.0 & 40.25 & 60.0 & 30.33 \\
\hline \multicolumn{6}{|c|}{ LSD at 0.05 for: } \\
\hline \multicolumn{2}{|c|}{ Plant extracts $(\mathrm{A})=$} & 2.08 & 0.98 & 2.08 & 0.99 \\
\hline \multicolumn{2}{|c|}{ Solvent types $(\mathrm{B})=$} & 3.57 & 1.28 & 3.09 & 1.16 \\
\hline \multicolumn{2}{|c|}{ Interaction $(\mathrm{A} \times \mathrm{B})=$} & 6.19 & 2.22 & 5.35 & 2.01 \\
\hline
\end{tabular}


Field experiments:

Soaking faba bean seeds in the aqueous and organic solvent extracts (Ethanol, acetone and ether) of $L$. inermis, M. oleifera and E. jambolana leaves before planting resulted in significant reduction of damping-off and root rot diseases incidence in the field during seasons of 2014/2015 and 2015/2016 as compared with the control (Table 3). Extracts of E. jambolana leaves and those of $M$. oleifera showed the lowest percentage of damping-off and root rot incidence without significant differences in both growing seasons and acetone extract was the most efficient one in both growing seasons, being 4.67 and $3.33 \%$ damping-off and 2.75 and $3.26 \%$ root rot in growing seasons $2014 / 15$ and 2015/16, respectively compared with the other extracts.

Table 3. Effect of seed soaking in aqueous and organic solvent extracts of $L$. inermis, $E$. jambolana and $M$. oleifera individually on the incidence of faba bean damping-off and root rot diseases under field conditions, during 2014-2015 and 2015-2016 growing seasons

\begin{tabular}{|c|c|c|c|c|c|}
\hline \multirow{2}{*}{$\begin{array}{c}\text { Source } \\
\text { of plant extract }\end{array}$} & \multirow[b]{2}{*}{ Solvent type } & \multicolumn{2}{|c|}{ Season 2014-2015 } & \multicolumn{2}{|c|}{ Season 2015-2016 } \\
\hline & & $\begin{array}{c}\% \\
\text { Damping-off }\end{array}$ & $\begin{array}{c}\% \\
\text { Root rot }\end{array}$ & $\begin{array}{c}\% \\
\text { Damping-off }\end{array}$ & $\begin{array}{c}\% \\
\text { Root rot } \\
\end{array}$ \\
\hline \multirow{5}{*}{ L. inermis } & Aqueous extract & 15.00 & 8.33 & 17.33 & 10.26 \\
\hline & Ethanol & 12.00 & 7.52 & 13.67 & 8.00 \\
\hline & Acetone & 8.67 & 5.49 & 10.00 & 5.00 \\
\hline & Ether & 10.33 & 6.96 & 12.67 & 7.67 \\
\hline & Mean & 11.50 & 7.08 & 13.42 & 7.73 \\
\hline \multirow{5}{*}{ E. jambolana } & Aqueous extract & 8.00 & 6.67 & 10.67 & 7.96 \\
\hline & Ethanol & 8.67 & 4.29 & 6.67 & 5.49 \\
\hline & Acetone & 4.67 & 2.75 & 3.33 & 3.26 \\
\hline & Ether & 8.67 & 5.49 & 10.00 & 4.67 \\
\hline & Mean & 7.50 & 4.80 & 7.67 & 5.35 \\
\hline \multirow{5}{*}{ M. oleifera } & Aqueous extract & 12.00 & 7.26 & 14.33 & 8.49 \\
\hline & Ethanol & 10.33 & 5.78 & 12.33 & 5.26 \\
\hline & Acetone & 6.33 & 6.67 & 7.67 & 7.25 \\
\hline & Ether & 11.67 & 8.29 & 13.67 & 9.67 \\
\hline & Mean & 10.08 & 7.00 & 12.00 & 7.67 \\
\hline \multicolumn{2}{|l|}{ Control } & 30.00 & 17.45 & 35.26 & 15.78 \\
\hline \multicolumn{6}{|l|}{ LSD at 0.05 for: } \\
\hline \multicolumn{2}{|l|}{ Plant extracts (A) } & 2.20 & 1.18 & 2.93 & 1.78 \\
\hline \multicolumn{2}{|l|}{ Solvent types (B) } & 0.84 & 0.53 & 1.08 & 0.60 \\
\hline Interaction $(\mathrm{A} \times \mathrm{B})$ & $=$ & 3.02 & 1.72 & 4.09 & 2.43 \\
\hline
\end{tabular}


Effect on some parameters and protein contents:

Data in Tables 4 and 5 indicate that faba bean seeds treated with any of the tested extracts significantly increased plant growth (plant height and number of branches/ plant) and yield component (No. of pods/plant, No. of seeds /plant, seed index, total yield /feddan) as well as protein content in the seeds during 2014/15 and 2015/16 growing seasons compared with untreated seeds (control). E. jambolana extracts recorded the highest increase of plant growth and yield components in both growing seasons followed by $L$. inermis extracts then the extracts of $M$. oleifera. On the other hand, organic solvent extracts increased plant growth and yield components more than the aqueous extracts of all the tested plants in both growing seasons. Generally, acetone extract was more effective in this respect than other extracts, especially in case of E. jambolana. Also, the results recorded in season 2015-16 were nearly similar to those of 2014-15 growing season.

Table 4. Effect of soaking faba bean seeds in aqueous and organic solvent extracts of $L$. inermis, $E$. jambolana and $M$. oleifera individually on some crop parameters and protein content under field conditions, during 2014-2015 growing season

\begin{tabular}{|c|c|c|c|c|c|c|c|c|}
\hline 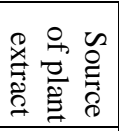 & $\begin{array}{c}\text { Solvent } \\
\text { type }\end{array}$ & $\begin{array}{l}\text { Plant } \\
\text { height } \\
(\mathrm{cm})\end{array}$ & $\begin{array}{c}\text { No. of } \\
\text { branches } \\
\text { /plant }\end{array}$ & $\begin{array}{c}\text { No.of } \\
\text { pods/ } \\
\text { plant }\end{array}$ & $\begin{array}{c}\text { No. of } \\
\text { seeds/ } \\
\text { plant }\end{array}$ & $\begin{array}{l}\text { Seed } \\
\text { index }\end{array}$ & $\begin{array}{c}\text { Total } \\
\text { yield } \\
\text { (Kg/fed.) }\end{array}$ & $\begin{array}{c}\text { Protein } \\
\text { content } \\
\%\end{array}$ \\
\hline \multirow{5}{*}{ 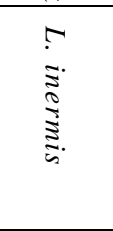 } & $\begin{array}{l}\text { Aqueous } \\
\text { extract }\end{array}$ & 99.30 & 3.50 & 17.40 & 50.30 & 76.90 & 1563.50 & 30.40 \\
\hline & Ethanol & 110.20 & 4.10 & 20.60 & 60.90 & 78.20 & 1689.30 & 31.20 \\
\hline & Acetone & 117.60 & 5.40 & 24.10 & 70.40 & 79.50 & 1875.30 & 31.40 \\
\hline & Ether & 115.70 & 5.10 & 22.70 & 65.40 & 77.90 & 1715.80 & 30.90 \\
\hline & Mean & 110.70 & 4.53 & 21.20 & 61.75 & 78.13 & 1710.98 & 30.98 \\
\hline \multirow{5}{*}{ 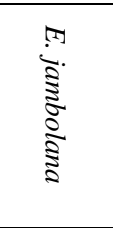 } & $\begin{array}{l}\text { Aqueous } \\
\text { extract }\end{array}$ & 105.70 & 4.40 & 19.30 & 56.80 & 77.80 & 1725.60 & 30.20 \\
\hline & Ethanol & 119.50 & 5.30 & 22.30 & 63.50 & 80.20 & 1836.90 & 31.40 \\
\hline & Acetone & 124.60 & 6.10 & 27.60 & 80.10 & 81.40 & 2142.30 & 31.80 \\
\hline & Ether & 118.40 & 5.70 & 25.00 & 70.20 & 80.00 & 2001.20 & 30.20 \\
\hline & Mean & 117.05 & 5.38 & 23.55 & 67.65 & 79.85 & 1926.50 & 30.90 \\
\hline \multirow{5}{*}{$\begin{array}{l}\frac{5}{9} \\
\frac{9}{2} \\
\frac{3}{2} \\
3\end{array}$} & $\begin{array}{l}\text { Aqueous } \\
\text { extract }\end{array}$ & 90.70 & 3.20 & 15.90 & 40.90 & 76.50 & 1452.30 & 29.20 \\
\hline & Ethanol & 100.40 & 4.00 & 17.50 & 48.20 & 78.50 & 1545.90 & 30.20 \\
\hline & Acetone & 114.40 & 4.80 & 19.90 & 55.40 & 79.50 & 1648.90 & 31.00 \\
\hline & Ether & 110.90 & 4.20 & 18.70 & 51.40 & 78.40 & 1548.90 & 30.70 \\
\hline & Mean & 104.10 & 4.05 & 18.00 & 48.98 & 78.23 & 1549.00 & 30.28 \\
\hline \multicolumn{2}{|c|}{ Control } & 80.50 & 2.60 & 11.50 & 30.50 & 70.20 & 896.30 & 27.50 \\
\hline \multicolumn{9}{|c|}{ LSD at 0.05 for: } \\
\hline \multicolumn{2}{|c|}{ Plant extracts $(\mathrm{A})=$} & 3.87 & 0.38 & 1.55 & 2.49 & 5.47 & 60.26 & 1.88 \\
\hline \multicolumn{2}{|c|}{ Solvent types $(\mathrm{B})=$} & 3.66 & 0.18 & 1.18 & 2.13 & 1.95 & 64.21 & 1.65 \\
\hline \multicolumn{2}{|c|}{ Interaction $(\mathrm{A} \times \mathrm{B})=$} & 7.12 & 0.53 & 2.75 & 4.72 & 7.02 & 130.21 & 3.24 \\
\hline
\end{tabular}


Table 5. Effect of soaking faba bean seeds in aqueous and organic solvent extracts of $L$. inermis, $E$. jambolana and M. oleifera individually on some crop parameters and protein content under field conditions, during 2015-2016 growing season

\begin{tabular}{|c|c|c|c|c|c|c|c|c|}
\hline $\begin{array}{c}\text { Source of } \\
\text { plant extract }\end{array}$ & $\begin{array}{l}\text { Solvent } \\
\text { type }\end{array}$ & 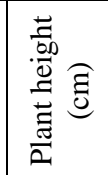 & 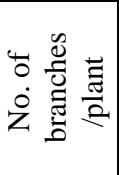 & 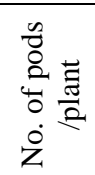 & 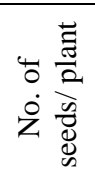 & 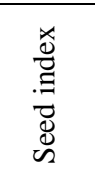 & 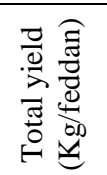 & 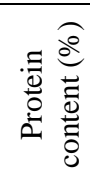 \\
\hline \multirow{5}{*}{ L. inermis } & \begin{tabular}{|l} 
Aqueous \\
extract
\end{tabular} & 106.80 & 3.20 & 18.40 & 47.20 & 75.90 & 1508.9 & 29.50 \\
\hline & \begin{tabular}{|l|} 
Ethanol \\
\end{tabular} & 112.40 & 4.20 & 21.60 & 59.60 & 77.40 & 1654.4 & 30.80 \\
\hline & Acetone & 119.80 & 5.30 & 25.40 & 70.90 & 78.90 & 1825.4 & 31.00 \\
\hline & Ether & 115.70 & 5.40 & 23.80 & 63.70 & 76.40 & 1689.7 & 29.70 \\
\hline & Mean & 113.68 & 4.53 & 22.30 & 60.35 & 77.15 & 1669.6 & 30.25 \\
\hline \multirow{5}{*}{ E. jambolana } & \begin{tabular}{|l}
$\begin{array}{l}\text { Aqueous } \\
\text { extract }\end{array}$ \\
\end{tabular} & 100.00 & 4.60 & 20.40 & 54.50 & 77.60 & 1731.8 & 30.40 \\
\hline & \begin{tabular}{|l|} 
Ethanol \\
\end{tabular} & 113.50 & 5.40 & 21.70 & 61.40 & 79.50 & 1802.6 & 31.20 \\
\hline & Acetone & 122.40 & 6.00 & 28.50 & 79.30 & 80.20 & 2100.3 & 31.40 \\
\hline & Ether & 116.80 & 5.80 & 26.70 & 68.70 & 79.10 & 1985.7 & 29.70 \\
\hline & Mean & 113.18 & 5.45 & 24.33 & 65.98 & 79.10 & 1905.1 & 30.68 \\
\hline \multirow{5}{*}{ M. oleifera } & \begin{tabular}{|l}
$\begin{array}{l}\text { Aqueous } \\
\text { extract }\end{array}$ \\
\end{tabular} & 93.50 & 3.30 & 16.00 & 38.90 & 75.40 & 1426.8 & 28.70 \\
\hline & \begin{tabular}{|l|} 
Ethanol \\
\end{tabular} & 102.40 & 4.20 & 17.40 & 48.70 & 77.40 & 1502.4 & 30.00 \\
\hline & \begin{tabular}{|l|} 
Acetone \\
\end{tabular} & 113.80 & 4.60 & 20.10 & 53.70 & 78.60 & 1625.7 & 30.70 \\
\hline & Ether & 111.20 & 4.00 & 17.90 & 50.20 & 78.40 & 1504.3 & 30.40 \\
\hline & Mean & 105.23 & 4.03 & 17.85 & 47.88 & 77.45 & 1514.8 & 29.95 \\
\hline \multicolumn{2}{|l|}{ Control } & 77.50 & 2.70 & 10.90 & 31.40 & 70.20 & 887.6 & 27.80 \\
\hline \multicolumn{9}{|c|}{ LSD at 0.05 for: } \\
\hline \multicolumn{2}{|c|}{ Plant extracts $(\mathrm{A})=$} & 5.18 & 0.36 & 1.74 & 3.27 & 2.67 & 61.89 & 1.62 \\
\hline \multicolumn{2}{|c|}{ Solvent types $(\mathrm{B})=$} & 3.32 & 0.20 & 1.34 & 2.26 & 1.90 & 59.95 & 1.36 \\
\hline \multicolumn{2}{|c|}{ Interaction $(\mathrm{A} \times \mathrm{B})$} & 9.21 & 0.58 & 3.12 & 5.62 & 4.62 & 125.42 & 3.21 \\
\hline
\end{tabular}

Biochemical changes in faba bean plants treated with plant extracts:

Peroxidase activity:

Results in Table 6 clearly show that all tested extracts of the three plant species increased activity of peroxidase (PO) enzyme in faba bean plants developed from treated seeds planted in artificially infested soil with any of $F$. solani and $R$. solani, compared to the control. Plants treated with E. jambolana extracts recorded the highest increase followed by $L$. inermis extracts. The lowest values of PO enzyme were recorded in plants treated with $M$. oleifera. On the other hand, treatments of faba bean seeds with organic solvent extracts increased PO enzyme activity more than those treated with aqueous extracts. Acetone and ether extracts of all tested plants recorded the highest increase compared with aqueous and Ethanol extracts. Also, activity of PO was lower in plants grown in soil infested with $F$. solani more than those grown in soil infested with $R$. solani (Table 6). 
Table 6. Effect of soaking faba bean seeds in aqueous and organic solvent extracts of $L$. inermis, $E$. jambolana and $M$. oleifera individually on the activity of peroxidase in plants grown in artificially infested soil with any of $\boldsymbol{F}$. solani or $R$. solani under greenhouse conditions

\begin{tabular}{|c|c|c|c|c|c|}
\hline \multirow{3}{*}{$\begin{array}{l}\text { Source } \\
\text { of plant } \\
\text { Extract }\end{array}$} & \multirow{3}{*}{ Solvent type } & \multicolumn{4}{|c|}{ PO activity (Enzyme unit $\min ^{-1} \mathrm{mg} \mathrm{protein}^{-1}$ ) } \\
\hline & & \multicolumn{2}{|c|}{ F. solani } & \multicolumn{2}{|c|}{ R. solani } \\
\hline & & Activity & $\%$ Increase $^{a}$ & Activity & $\%$ Increase \\
\hline \multirow{4}{*}{ L. inermis } & Aqueous extract & 0.988 & 54.86 & 1.096 & 45.74 \\
\hline & Ethanol & 1.172 & 83.70 & 1.165 & 54.92 \\
\hline & Acetone & 1.205 & 88.87 & 1.221 & 62.37 \\
\hline & Ether & 1.288 & 101.88 & 1.263 & 67.95 \\
\hline \multirow{4}{*}{$\begin{array}{l}\text { E. } \\
\text { jambolana }\end{array}$} & Aqueous extract & 1.025 & 60.66 & 1.156 & 53.72 \\
\hline & Ethanol & 1.196 & 87.46 & 1.259 & 67.42 \\
\hline & Acetone & 1.251 & 96.08 & 1.349 & 79.39 \\
\hline & Ether & 1.305 & 104.55 & 1.359 & 80.72 \\
\hline \multirow{4}{*}{ M. oleifera } & Aqueous extract & 0.901 & 41.22 & 1.025 & 36.30 \\
\hline & Ethanol & 1.148 & 79.94 & 1.141 & 51.73 \\
\hline & Acetone & 1.198 & 87.77 & 1.196 & 59.04 \\
\hline & Ether & 1.263 & 97.96 & 1.215 & 61.57 \\
\hline \multicolumn{2}{|l|}{ Control } & 0.638 & 0.00 & 0.752 & 0.00 \\
\hline
\end{tabular}

${ }^{\text {a }}$ Increase to untreated control plants

Polyphenoloxidase activity:

The activity of polyphenoloxidase (PPO) was increased in plants grown from seeds treated with any of the tested plant extracts compared with untreated seeds under artificial infestation with $F$. solani or $R$. solani (Table 7). E. jambolana followed by $L$. inermis extracts recorded the highest increase in activity (\%) of PPO in plants grown in soil infested with any of the two tested fungi. While, M. oleifera extracts gave the lowest increase in this respect. Ether extract of all tested plant species recorded higher increase compared with the other extracts (aqueous, Ethanol and acetone) either in plants inoculated with $F$. solani or $R$. solani. Generally, ether extract of $E$. jambolana recorded the highest increase of PPO activity, being 65.05 and $61.16 \%$ increase of activity in case of soil infestation with $F$. solani and $R$. solani, respectively.

Phenyalalanine ammonia lyase activity:

The activity of phenyalalanine ammonia lyase (PAL) was increased due to treating faba bean seeds with aqueous and organic solvent (Ethanol, acetone, ether) extracts of $L$. inermis, E. jambolana and $M$. oleifera leaves of plants grown under artificially infested soil with any of $F$. solani or, $R$. solani (Table 8 ). The obtained data indicate that $E$. jambolana extracts recorded the highest increase in all types of extracts compared with those of $L$. inermis and $M$. oleifera. Organic solvent extracts increased activity of PAL enzyme more than aqueous extract in all tested plants. Also, acetone extracts of all tested plants recorded the highest increase in activity of PAL enzyme compared with the other types of extracts. 
Table 7. Effect of soaking faba bean seeds in aqueous and organic solvent extracts of $L$. inermis, $E$. jambolana and $M$. oleifera individually on the activity of polyphenoloxidase (PPO) in plants grown in soil infested with any of $F$. solani or $R$. solani under greenhouse conditions

\begin{tabular}{|c|c|c|c|c|c|}
\hline \multirow{3}{*}{$\begin{array}{l}\text { Source of } \\
\text { plant extract }\end{array}$} & \multirow{3}{*}{ Solvent type } & \multicolumn{4}{|c|}{ PPO activity (Enzyme unit $\min ^{-1} \mathrm{mg}_{\text {protein }}{ }^{-1}$ ) } \\
\hline & & \multicolumn{2}{|c|}{ F. solani } & \multicolumn{2}{|c|}{ R. solani } \\
\hline & & Activity & $\%$ Increase & Activity & $\%$ Increase \\
\hline \multirow{4}{*}{ L. inermis } & Aqueous extract & 1.028 & 24.30 & 1.148 & 18.60 \\
\hline & Ethanol & 1.148 & 38.81 & 1.256 & 29.75 \\
\hline & Acetone & 1.196 & 44.62 & 1.325 & 36.88 \\
\hline & Ether & 1.251 & 51.27 & 1.345 & 38.95 \\
\hline \multirow{4}{*}{$\begin{array}{l}\text { E. } \\
\text { jambolana }\end{array}$} & Aqueous extract & 1.099 & 32.89 & 1.199 & 23.86 \\
\hline & Ethanol & 1.189 & 43.77 & 1.298 & 34.09 \\
\hline & Acetone & 1.254 & 51.63 & 1.396 & 44.21 \\
\hline & Ether & 1.365 & 65.05 & 1.560 & 61.16 \\
\hline \multirow{4}{*}{ M. oleifera } & Aqueous extract & 1.000 & 20.92 & 1.025 & 5.89 \\
\hline & Ethanol & 1.144 & 38.33 & 1.196 & 23.55 \\
\hline & Acetone & 1.201 & 45.22 & 1.241 & 28.20 \\
\hline & Ether & 1.224 & 48.00 & 1.428 & 47.52 \\
\hline \multicolumn{2}{|l|}{ Control } & 0.827 & 0.00 & 0.968 & 0.00 \\
\hline
\end{tabular}

Table 8. Effect of soaking faba bean seeds in aqueous and organic solvent extracts of L. inermis, E. jambolana and M. oleifera individually on the activity of Phenyalalanine ammonia lyase (PAL) in plants grown in soil infested with any of $\boldsymbol{F}$. solani or $\boldsymbol{R}$. solani under greenhouse conditions

\begin{tabular}{|c|c|c|c|c|c|}
\hline \multirow{3}{*}{$\begin{array}{c}\text { Source of } \\
\text { plant extract }\end{array}$} & \multirow{3}{*}{ Solvent type } & \multicolumn{4}{|c|}{ PAL activity (Enzyme unit min $^{-1} \mathrm{mg}$ protein ${ }^{-1}$ ) } \\
\hline & & \multicolumn{2}{|c|}{ F. solani } & \multicolumn{2}{|c|}{ R. solani } \\
\hline & & Activity & $\%$ Increase & Activity & $\%$ Increase \\
\hline \multirow{4}{*}{ L. inermis } & $\begin{array}{l}\text { Aqueous } \\
\text { extract }\end{array}$ & 4.396 & 30.87 & 4.256 & 36.19 \\
\hline & Ethanol & 5.575 & 65.97 & 5.021 & 60.67 \\
\hline & Acetone & 6.354 & 89.16 & 5.624 & 79.97 \\
\hline & Ether & 6.124 & 82.32 & 5.472 & 75.10 \\
\hline \multirow{4}{*}{ E. jambolana } & $\begin{array}{l}\text { Aqueous } \\
\text { extract }\end{array}$ & 5.214 & 55.22 & 4.856 & 55.39 \\
\hline & Ethanol & 5.895 & 75.50 & 5.635 & 80.32 \\
\hline & Acetone & 6.742 & 100.71 & 6.256 & 100.19 \\
\hline & Ether & 6.235 & 85.62 & 6.124 & 95.97 \\
\hline \multirow{4}{*}{ M. oleifera } & $\begin{array}{l}\text { Aqueous } \\
\text { extract }\end{array}$ & 4.214 & 25.45 & 3.968 & 26.98 \\
\hline & Ethanol & 4.365 & 29.95 & 4.256 & 36.19 \\
\hline & Acetone & 5.326 & 58.56 & 4.869 & 55.81 \\
\hline & Ether & 5.124 & 52.55 & 4.789 & 53.25 \\
\hline \multicolumn{2}{|l|}{ Control } & 3.359 & 0.00 & 3.125 & 0.00 \\
\hline
\end{tabular}

Superoxide dismutase activity:

Data presented in Table 9 indicate that all plant extracts either aqueous or organic solvent extracts of the tested plant species increased activity of superoxide dismutase (SOD) enzyme compared with untreated seeds (control) under artificial 
soil infestation with any of $F$. solani and $R$. solani. Faba bean seeds treated with $E$. jambolana extract recorded the highest activity compared to the other tested plants under artificial soil infestation with the two tested fungi.

Table 9. Effect of soaking faba bean seeds in aqueous and organic solvent extracts of $L$. inermis, E. jambolana and M. oleifera individually on the activity of superoxide dismutase (SOD) in plants grown in soil infested with any of $F$. solani or $\boldsymbol{R}$. solani under greenhouse conditions

\begin{tabular}{|c|l|c|c|c|c|}
\hline \multirow{2}{*}{$\begin{array}{c}\text { Source of } \\
\text { plant extract }\end{array}$} & \multirow{2}{*}{$\begin{array}{c}\text { Solvent } \\
\text { type }\end{array}$} & \multicolumn{3}{|c|}{ SOD activity (Enzyme unit min $^{-1}$ mg protein $^{-1}$ ) } \\
\cline { 3 - 6 } & & \multicolumn{2}{|c|}{$F$. solani } & \multicolumn{2}{|c|}{. solani } \\
\cline { 3 - 6 } & $\begin{array}{l}\text { Aqueous } \\
\text { extract }\end{array}$ & 6.589 & 44.24 & 8.268 & \% Increase \\
\cline { 2 - 6 } & Ethanol & 7.598 & 66.33 & 9.784 & 52.61 \\
\cline { 2 - 6 } & Acetone & 9.002 & 97.07 & 12.478 & 100.13 \\
\cline { 2 - 6 } & Ether & 10.472 & 129.25 & 11.457 & 83.75 \\
\hline \multirow{4}{*}{ E. jambolana } & $\begin{array}{l}\text { Aqueous } \\
\text { extract }\end{array}$ & 8.457 & 85.14 & 9.856 & 58.08 \\
\cline { 2 - 6 } & Ethanol & 10.247 & 124.32 & 10.478 & 68.05 \\
\cline { 2 - 6 } & Acetone & 11.240 & 146.06 & 13.427 & 115.35 \\
\cline { 2 - 6 } & Ether & 11.012 & 141.07 & 13.024 & 108.89 \\
\hline \multirow{4}{*}{ M. oleifera } & $\begin{array}{l}\text { Aqueous } \\
\text { extract }\end{array}$ & 7.012 & 53.50 & 7.986 & 28.08 \\
\cline { 2 - 6 } & Ethanol & 8.012 & 75.39 & 8.967 & 43.82 \\
\cline { 2 - 6 } & Acetone & 9.214 & 101.71 & 10.002 & 60.42 \\
\cline { 2 - 6 } & Ether & 10.427 & 128.26 & 11.424 & 83.22 \\
\hline Control & & 4.568 & 0.00 & 6.235 & 0.00 \\
\hline
\end{tabular}

On the other hand, organic solvent extracts recorded the highest increase compared with aqueous extracts of all the tested plants under soil infestation with any of the two tested pathogenic fungi. Also, acetone extract of E. jambolana gave the highest activity of SOD enzyme, being 146.06 and $115.35 \%$ in case of soil infestation with $F$. solani or $R$. solani, respectively. The activity of SOD enzyme in plants grown in pots inoculated with $R$. solani was higher than those grown in soil infested with $F$. solani. In contrary, the increase of SOD enzyme activity was higher in case of $F$. solani than that of $R$. solani in all treatments.

\section{Catalase activity:}

Data presented in Table 10 show that all tested plant extracts increased activity of catalase enzyme (CA) compared with untreated seeds (control) under artificial inoculation with $R$. solani or $F$. solani. Aqueous extracts of all tested plants recorded the lowest increase in activity of the CA enzyme compared with the organic solvent extracts (Ethanol, acetone, ether) in all tested plants. The E. jambolana extracts recorded the highest increase of activity in both cases of inoculation with $R$. solani and $F$. solani. However, CA activity in faba bean plants grown in pots inoculated with $R$. solani was higher than the activity of the CA enzyme in plants grown in pots inoculated with $F$. solani in all tested plant extracts. 
Table 10. Effect of soaking faba bean seeds in aqueous and organic solvent extracts of $L$. inermis, $E$. jambolana and M. oleifera individually on the activity of catalase (CA) in plants grown in soil infested with any of $\boldsymbol{F}$. solani or $\boldsymbol{R}$. solani under greenhouse conditions

\begin{tabular}{|c|c|c|c|c|c|}
\hline \multirow{3}{*}{$\begin{array}{c}\text { Source of } \\
\text { plant extract }\end{array}$} & \multirow{3}{*}{$\begin{array}{l}\text { Solvent } \\
\text { type }\end{array}$} & \multicolumn{4}{|c|}{$\begin{array}{c}\text { CA activity }\left(\mu \text { moles } \mathrm{H}_{2} \mathrm{O}_{2} \text { decomposed } \mathrm{mg}^{-1}\right. \\
\left.\text { protein } \min ^{-1}\right)\end{array}$} \\
\hline & & \multicolumn{2}{|c|}{ F. solani } & \multicolumn{2}{|c|}{ R. solani } \\
\hline & & Activity & $\%$ Increase & Activity & $\%$ Increase \\
\hline \multirow{4}{*}{ L. inermis } & $\begin{array}{l}\text { Aqueous } \\
\text { extract }\end{array}$ & 11.210 & 36.14 & 17.245 & 53.36 \\
\hline & Ethanol & 12.412 & 50.74 & 18.256 & 62.35 \\
\hline & Acetone & 13.421 & 62.99 & 21.142 & 88.01 \\
\hline & Ether & 14.215 & 72.64 & 22.145 & 96.93 \\
\hline \multirow{4}{*}{ E. jambolana } & $\begin{array}{l}\text { Aqueous } \\
\text { extract }\end{array}$ & 12.475 & 51.51 & 18.241 & 62.21 \\
\hline & Ethanol & 14.124 & 71.53 & 21.421 & 90.49 \\
\hline & Acetone & 16.524 & 100.68 & 23.457 & 108.60 \\
\hline & Ether & 16.523 & 100.67 & 24.124 & 114.53 \\
\hline \multirow{4}{*}{ M. oleifera } & $\begin{array}{l}\text { Aqueous } \\
\text { extract }\end{array}$ & 9.362 & 13.70 & 13.214 & 17.51 \\
\hline & Ethanol & 10.214 & 24.05 & 14.256 & 26.78 \\
\hline & Acetone & 11.245 & 36.57 & 16.547 & 47.15 \\
\hline & Ether & 12.020 & 45.98 & 17.025 & 51.40 \\
\hline \multicolumn{2}{|l|}{ Control } & 8.234 & 0.00 & 11.245 & 0.00 \\
\hline
\end{tabular}

Total phenol contents:

The content of total phenolic compounds was greatly increased in plants treated with different aqueous and organic solvent extracts, compared with untreated plants (Table 11). Maximum increase in total phenols was recorded in plants treated with $E$. jambolana under artificial soil infestation with any of $F$. solani and $R$. solani. The organic solvent extracts of all tested plants increased the phenolic contents in faba bean plants more than in the plants treated with aqueous extracts. Ether extracts of all tested plants recorded the highest increase of phenolic contents in faba bean plants grown in soil infested with any of the two pathogenic fungi compared with the other plant extracts. 
Table 11. Effect of soaking faba bean seeds in aqueous and organic solvent extracts of $L$. inermis, $E$. jambolana and M. oleifera individually on phenolic compounds in plants grown in soil infested with any of $F$. solani and $R$. solani under greenhouse conditions

\begin{tabular}{|c|c|c|c|c|c|}
\hline \multirow{3}{*}{$\begin{array}{c}\text { Source of } \\
\text { plant extract }\end{array}$} & \multirow{3}{*}{$\begin{array}{l}\text { Solvent } \\
\text { type }\end{array}$} & \multicolumn{4}{|c|}{ Total phenolic contents $\left(\mu \mathrm{g} \mathrm{gm}^{-1}\right.$ fresh weight $)$} \\
\hline & & \multicolumn{2}{|c|}{ F. solani } & \multicolumn{2}{|c|}{ R. solani } \\
\hline & & $\begin{array}{c}\text { TPC } \\
\text { contents }\end{array}$ & $\%$ Increase & $\begin{array}{c}\text { TPC } \\
\text { contents }\end{array}$ & $\%$ Increase \\
\hline \multirow{4}{*}{ L. inermis } & $\begin{array}{l}\text { Aqueous } \\
\text { extract }\end{array}$ & 2.312 & 17.66 & 2.656 & 32.01 \\
\hline & Ethanol & 2.752 & 40.05 & 2.965 & 47.37 \\
\hline & Acetone & 2.865 & 45.80 & 3.512 & 74.55 \\
\hline & Ether & 3.021 & 53.74 & 3.968 & 97.22 \\
\hline \multirow{4}{*}{ E. jambolana } & $\begin{array}{l}\text { Aqueous } \\
\text { extract }\end{array}$ & 2.546 & 29.57 & 3.324 & 65.21 \\
\hline & Ethanol & 2.965 & 50.89 & 3.996 & 98.61 \\
\hline & Acetone & 3.568 & 81.58 & 4.826 & 139.86 \\
\hline & Ether & 3.985 & 102.80 & 4.965 & 146.77 \\
\hline \multirow{4}{*}{ M. oleifera } & $\begin{array}{l}\text { Aqueous } \\
\text { extract }\end{array}$ & 2.201 & 12.01 & 2.302 & 14.41 \\
\hline & Ethanol & 2.513 & 27.89 & 2.614 & 29.92 \\
\hline & Acetone & 2.825 & 43.77 & 2.954 & 46.82 \\
\hline & Ether & 2.968 & 51.04 & 3.324 & 65.21 \\
\hline \multicolumn{2}{|l|}{ Control } & 1.965 & 0.00 & 2.012 & 0.00 \\
\hline
\end{tabular}

\section{D i s c us i o n}

Plant extracts may contain natural antimicrobial compounds, and these can be used for seed disinfection as an alternative to fungicide treatments. Using of plant extracts against plant pathogenic fungi is relatively a recent approach. In this study, aqueous and organic solvent extracts (Ethanol, acetone and ether) of L. inermis, E. jambolana and $M$. oleifera were evaluated for controlling damping-off and root rot diseases caused by $F$. solani and $R$. solani in faba bean plants in vitro and in vivo.

The obtained data indicated that all the tested plant extracts significantly reduced the linear growth of the tested fungi in vitro. Organic solvent extracts were more effective for suppressing linear growth of both tested pathogenic fungi than aqueous extracts of all tested plant species. E. jambolana extracts recorded the highest reduction in growth of $F$. solani and $R$. solani.

Also, under greenhouse and field conditions, faba bean cv. Misr 1 treated with any of the tested extracts of the three plant species significantly reduced dampingoff and root rot incidence compared with untreated seeds (control) as well as they increased plant growth (plant height and No. of branches/plant) and yield components (No. of pods/plant, No. of seeds/plant, seed index, seed yield weight /feddan and protein content in seeds) during growing seasons of 2014-15 and 20152016. E. jambolana extracts caused the highest reduction of damping-off and root 
rot incidence and gave the highest increase in plant growth and yield components compared with the other two tested plants. On the other hand, organic solvent extracts were more effective than aqueous extracts for all the tested plant species under greenhouse and field conditions.

This may be due to the solvent that has potential to extract the different constituents that having antimicrobial activity. The inhibitory effect of the tested extracts might be due to natural bioactive materials present in these extracts (AbdelMonaim et al., 2011 and Atta et al., 2013). In this respect, the hydroalcoholic extract of E. jambolana leaves is shown to possess antifungal effects against Candida albicans and C. krusei (De Oliveira et al., 2007). The aqueous and methanolic seed extracts inhibited growth of dermatophytic fungi C. albicans, Trichophyton rubrum, T. mentagrophytes and Microsporum gypseum (Chandrasekaran and Venkatesalu 2004). The aqueous, ethanol and n-hexane extracts from the leaves, fruits, root-bark and stem-bark possess growth inhibitory effects on Ascochyta rabiei, the causative agent of blight disease in chickpea (Cicer arietinum L.) suggesting its use as a nontoxic agent effective in preventing food infestation by fungi. The aqueous extracts of all the four Syzygium cumini (L.) parts showed significant antifungal activity (Jabeen and Javaid, 2010). However, the essential oil from the leaves of E. jambolana is shown to contain the phytochemicals pinocarveol, $\alpha$-terpeneol, myrtenol, eucarvone, muurolol, $\alpha$-myrtenal, cineole, geranyl acetone, $\alpha$-cadinol and pinocarvone (Shafi et al., 2002). On the other hand, L. inermis (Henna) has been used for more than 4000 years as a cosmetic by Mediterranean, Middle Eastern, and Asian cultures. Aqueous extract of L. inermis (Henna) leaves was tested for antifungal activity against eight important isolated species of Aspergillus from sorghum, maize, and paddy seed samples. A. flavus showed high sensitivity toward henna (Raveesha et al., 2007). Ethanol, methanol, and aqueous extracts of $L$. inermis leaves were involved also in defensive mechanism against spore germination of Drechslera oryzae (Natarajan and Lalitha, 1987).

Some authors reported that the origin of the antimicrobial activity of $L$. inermis leaves to gallic acid or naphthoquinones (lawsone) (Cowan, 1999 and Ahmed et al., 2000). It was reported that lawsone isolated from the leaves of $L$. inermis has shown a significant antifungal effect (Tripathi et al., 1978 and Dixit et al., 1980). However, Rahmoun et al. (2013) thought there is a role of polyphenols in the antifungal activity showed by the ethanol extract. The polyphenols isolated from the ethanol extract are: naphthoquinones derivatives, lawsoniaside, luteolin, acacetin, cosmosiin, lalioside, lawsoniaside, syringinoside, daphneside, daphnorin, agrimonolide pyranoside derivatives and isoscutellarin (Takeda and Fatope, 1988 and Cuong et al., 2010). Moreover, ethanolic extract of M. oleifera leaves showed antifungal activity against a number of dermatophytes (Chuang et al., 2007). Leaves of M. oleifera contain Phytochemicals like tannins, sterols, saponins, trepenoids, phenolics, alkaloids and flavanoids like quercitin, isoquercitin, kaemfericitin, isothiocyanates and glycoside compounds (Gopalakrishnan et al., 2016).

Also, other investigators found an antifungal activity of some natural plant products suppressed plant pathogens with an increase of oxidative enzymes in plants that can play an important role in the resistance to infection with diseases and 
consequently increasing growth parameters and seed yield (Mohamed and ElHadidy, 2008; Abdel-Monaim et al., 2011 and Goel and Paul, 2015). Investigations on the mechanisms of disease suppression by plant products have suggested that the active principles present in them may either act on the pathogen directly (Baraka et $a l .$, 2006). In this study, all tested extracts resulted in increasing the activity of oxidative enzymes, viz. peroxidase (PO), polyphenoloxidase (PPO), phenylalanine ammonia lyase (PAL), superoxide dismutase (SOD) and catalase (CA) as well as total phenolic contents in faba bean plants compared with untreated seeds. $E$. jambolana extracts gave the highest activity of all tested oxidative enzymes and total phenols content. Also, organic solvent extracts of all tested plant species increased the activity of these enzymes and phenols more than aqueous extracts. Many researches showed that the application of some plant extracts can induce systemic resistance in many plants through accumulations of oxidative enzymes, pathogenesis related proteins (PR-proteins) and phenolic compounds (Kagale et al., 2004 and 2011; Farag et al., 2011 and Baka, 2015).

As a conclusion, our study demonstrated that some plant extracts can be used as alternative source of antifungal agents for protecting faba bean plants from dampingoff and root rot diseases. Thus, this method can contribute to minimizing the risk and hazard of toxic fungicides.

\section{$R$ e f e r e n e s}

Abdel-Monaim, M.F. 2013. Improves biocontrol of damping-off and root rot/wilt of faba bean by salicylic acid and hydrogen peroxide. Mycobiol., 41(1):47-55.

Abdel-Monaim, M.F.; Abo-Elyousr, K.A.M. and Morsy, K.M. 2011. Effectiveness of plant extracts on suppression of damping-off and wilt diseases of lupine (Lupinus termis Forsik). Crop Prot., 30:185-191.

Aboellil, A.H. 2007. Trilogy, a product of neem (Azadirachta indica) induces resistance in cucumber against Podosphaera xanthi. Res. J. Microbiol., 2:402414.

Aebi, M. 1984. Catalase in vitro. Methods in Enzymol., 105:121-126.

Ahmed, S.; Rahman, A.; Alam, A.; Saleem, M.; Athar, M. and Sultana, S. (2000). Evaluation of the efficacy of Lawsonia alba in the alleviation of carbon tetrachloride-induced oxidative stress. J. Ethnopharmacol., 69:157-164.

Anonymous, 1991. A Software Program for the MSTAT-C Design, Management and Analysis of Agronomic Research Experiments. Michigan State University.

Anonymous, 2000. Official Methods of Analysis Association of Official Analysis Chemists. $25^{\text {th }}$ Ed., AOAC, Washington D.C., USA.

Atta, E.M.; Hashem, A.I. and Eman, R.E.S. 2013. A novel flavonoid compound from Farsetia aegyptia and its antimicrobial activity. Chem. Natural Comp., 49:432-436. 
Baka, Z.A.M. 2015. Efficacy of wild medicinal plant extracts against predominant seed-borne fungi of broad bean cultivars. Acta Phytopathologica et Entomologica Hungarica, 50 (1): 45-65.

Baraka, M.A.; Omar, S.A.; El-Barougy, Ebtehage and Zian, A.H. 2006. Controlling seedling damping-off, root rot and wilt diseases of lupine (Lupinus albus L.). Agric. Res. J. Suez Canal Univ., 6: 57-68.

Biles, C.L. and Martyn, R.D. 1993. Peroxidase, polyphenoloxidase, and shikimate dehydrogenase isozymes in relation to tissue type, maturity and pathogen induction of watermelon seedlings. Plant Physiol Biochem., 31:499-506.

Bradford, M. 1976. A rapid and sensitive method for the quantitation of Microgram quantities of protein utilizing the principle of protein dye binding. Anal. Biochem., 72:248-250.

Cavalcanti, F.R.; Resendea, M.L.V.; Carvalhoc, C.P.S.; Silveirab, J.A.G. and Oliveira, J.T.A. 2007. An aqueous suspension of Crinipellis perniciosa mycelium activates tomato defense responses against Xanthomonas vesicatoria. Crop Prot., 6:729-738.

Chandrasekaran, M. and Venkatesalu, V. 2004. Antibacterial and antifungal activity of Syzygium jambolanum seeds. J. Ethnopharmacolol., 91: 105-108.

Chuang, P.H.; Lee, C.W.; Chou, J.Y.; Murugan, M.; Shieh, B.J. and Chen, H.M. 2007. Anti-fungal activity of crude extracts and essential oil of Moringa oleifera Lam. Bioresource Technol., 98: 232-236

Cowan, M.M. 1999. Plant products as antimicrobial agents. Clin. Microbiol. Rev., 12:564-582.

Cuong, N.X.; Nhiem, N.X.; Thao, N.P.; Nam, N.H.; Dat, N.T. and Le Tuan-Anh, H. 2010. Inhibitors of osteoclastogenesis from Lawsonia inermis leaves. Bioorg \& Med Chem Lett., 20(16): 4782-4784.

De Oliveira, G.F.; Furtado, N.A.J.C.; da Silva-Filho, A.A.; Martins, C.H.G.; Bastos, J.K. and Cunha, W.R. 2007. Antimicrobial activity of Syzygium cumini (Myrtaceae) leaves extract. Brazilian J. Microbiol., 38:381-384.

Dhindsa, R.H.; Plumb-Dhindsa, R. and Thorpe, T.A. 1981. Leaf senescence correlated with increased level of membrane permeability, lipid peroxidation and decreased level of SOD and CAT. J. Exp. Bot., 32:93-101.

Dixit, S.N., Srivastava, H.S. and Tripathi, R.D. 1980. Lawsone, the antifungal antibiotic from the leaves of Lawsonia inermis and some aspects of its mode of action. Indian Phytopathol., 31:131-133.

Farag, H.R.M.; Abdou Z.A.; Salama D.A.; Ibrahim M.A.R. and Sror, H.A.M. 2011. Effect of neem and willow aqueous extracts on Fusarium wilt disease in tomato seedlings: Induction of antioxidant defensive enzymes. Ann. Agric. Sci., 56:1-7.

Gauillard, F.; Richard-Forget, F. and Nicolas, J. 1993. New spectrophotometric assay for polyphenol oxidase activity. Anal. Biochem., 215:59-65. 
Goel, N. and Paul, P.K. 2015. Polyphenoloxidase and lysozyme mediate induction of systemic resistance in tomato, when a bioelicitor is used. J. Plant Prot. Res. 55:343-350.

Gomez, K.A. and Gomez, A.A. 1984. Statistical Procedures for Agricultural Research. Wiley-interscience Publication, New York, 680p.

Gopalakrishnan, L.; Doriyaa, K. and Kumar, D.S. 2016. Moringa oleifera: A review on nutritive importance and its medicinal application. Food Sci. Human Wellness, 5:49-56.

Guleria, S. and Kumar, A. 2006. Azadirachta indica leaf extract induces resistance in sesame against Alternaria leaf spot disease. J. of Cell Mol. Bio., 5:81-86.

Hammerschmidt, R.; Nuckles, E.M. and Kuc, J. 1982. Association of enhanced peroxidase activity with induced systemic resistance of cucumber to Colletotrichum lagenarium. Physiol. Plant Pathol., 20:73-82.

Jabeen, K. and Javaid, A. 2010. Antifungal activity of Syzygium cumini against Ascochyta rabiei - the cause of chickpea blight. Natural Product Res., 24:1158-1167.

Joseph, B.; Dar, M.A. and Kumar, V. 2008. Bioefficacy of plant extracts to control Fusarium solani f. sp. melongenae incitant of brinjal wilt. Global J. Biotech. Biochem., 3(2):56-59.

Kagale, S.; Marimuthu, T.; Kagale, J.; Thayumanavan, B. and Samiyappan, R., 2011. Induction of systemic resistance in rice by leaf extracts of Zizyphus jujube and Ipomoea carnea against Rhizoctonia solani. Plant Signaling Behavior, 6:919923.

Kagale, S.; Marimuthu, T.; Thayumanavan, B.; Nandakumar, R. and Samiyappan, R. 2004. Antimicrobial activity and induction of systemic resistance in rice by leaf extract of Datura metel against Rhizoctonia solani and Xanthomonas oryzae pv. oryzae. Physiol. Mol. Plant Pathol., 65:91-100.

Leslie, J.F. and Summerell, B.A. 2006. The Fusarium Laboratory Manual. Blackwell Publishing, Iowa, USA, 388p.

Liu, L.; Kloepper, J.W. and Tuzun, S. 1995. Introduction of systemic resistance in cucumber against Fusarium wilt by plant growth-promoting Rhizobacteria. Phytopathol., 85:695-698.

Maxwell, D.P. and Bateman, D.F. 1967. Change in the activities of some oxidases in extracts of Rhizoctonia infected bean hypocotyls in relation to lesion maturation. Phytopathology, 57:132-136.

Mohamed, N.H. and El-Hadidy, A.M. 2008. Studies of biologically active constituents of Verbascum eremobium Murb. and its inducing resistance against some diseases of cucumber. Egypt. J. Phytopathol. 36:133-150. 
Natarajan, M.R. and Lalitha, D.K. 1987. Leaf extracts of Lawsonia inermis as antifungal agent. Curr. Sci., 56:1021-1022.

Rahmoun, N.; Boucherit-Otmani, Z.; Boucherit, K.; Benabdallah, M. and Choukchou-Braham, N. 2013. Antifungal activity of the Algerian Lawsonia inermis (henna). Pharmaceutical Biol., 51(1):131-135.

Raveesha, K.A.; Satish, S.; Mohana, D.C. and Raghavendra, M.P. 2007. Antifungal activity of some plant extracts against important seed borne pathogens of Aspergillus sp. J. Agric. Technol., 3: 109-119.

Sadda, N. and Varma, R. 2015. Bioefficacy of plant extracts in the control of root rot disease of sponge gourd. J. Indian Bot. Soc., 94(1-2):126-130.

Saikia, R.; Yadav, M.; Varghese, S.; Singh, B.P.; Gogoi, D.K.; Kuma, R. and Arora, K.D., 2006. Role of Riboflavin in induced resistance against Fusarium wilt and charcoal rot diseases of chickpea. Plant Pathol. J., 22(4):339-347.

Shafi, P.M.; Rosamma, M.K.; Jamil, K. and Reddy, P.S. 2002. Antibacterial activity of Syzygium cumini and Syzygium travancoricum leaf essential oils. Fitoterapia, 73:414-416.

Singh, A.K.; Bharati, R.C.; Manibhushan, N.C. and Pedpati, A. 2013. An assessment of faba bean (Vicia faba L.) current status and future prospect. Afr. J. Agric. Res., 8(50):6634-6641.

Sneh, B.; Burpee, L. and Ogoshi, A. 1991. Identification of Rhizoctonia species. American Phytopathological Society Press, Saint Paul, USA. 133p.

Somda, I.; Leth, V. and Seeme, P. 2007. Evaluation of lemongrass, eucalyptus and neem aqueous extracts for controlling seed-borne fungi of sorghum grown in Burkina Faso. World J. Agric. Sci., 3:218-223.

Takeda, Y. and Fatope, M.O. 1988. New phenolic glucosides from Lawsonia inermis. J. Nat. Prod., 51: 725-729.

Tripathi, R.D.; Srivastava, H.S. and Dixit, S.N. 1978. A fungitoxic principle from the leaves of Lawsonia inermis Lam. Experientia, 34:51-52.

Urbanek, H.; Kuzniak-Gebarowska, E. and Herka, H. 1991. Elicitation of defense responses in bean leaves by Botrytis cinerea polygalacturonase. Acta Physiol. Plant, 13:43-50.

Wang, J.; Liu, H. and Ren, G. 2014. Near-infrared spectroscopy (NIRS) evaluation and regional analysis of Chinese faba bean (Vicia faba L.). The Crop J., 2:28-37.

(Received 09/05/2017; in revised form 05/06/2017) 

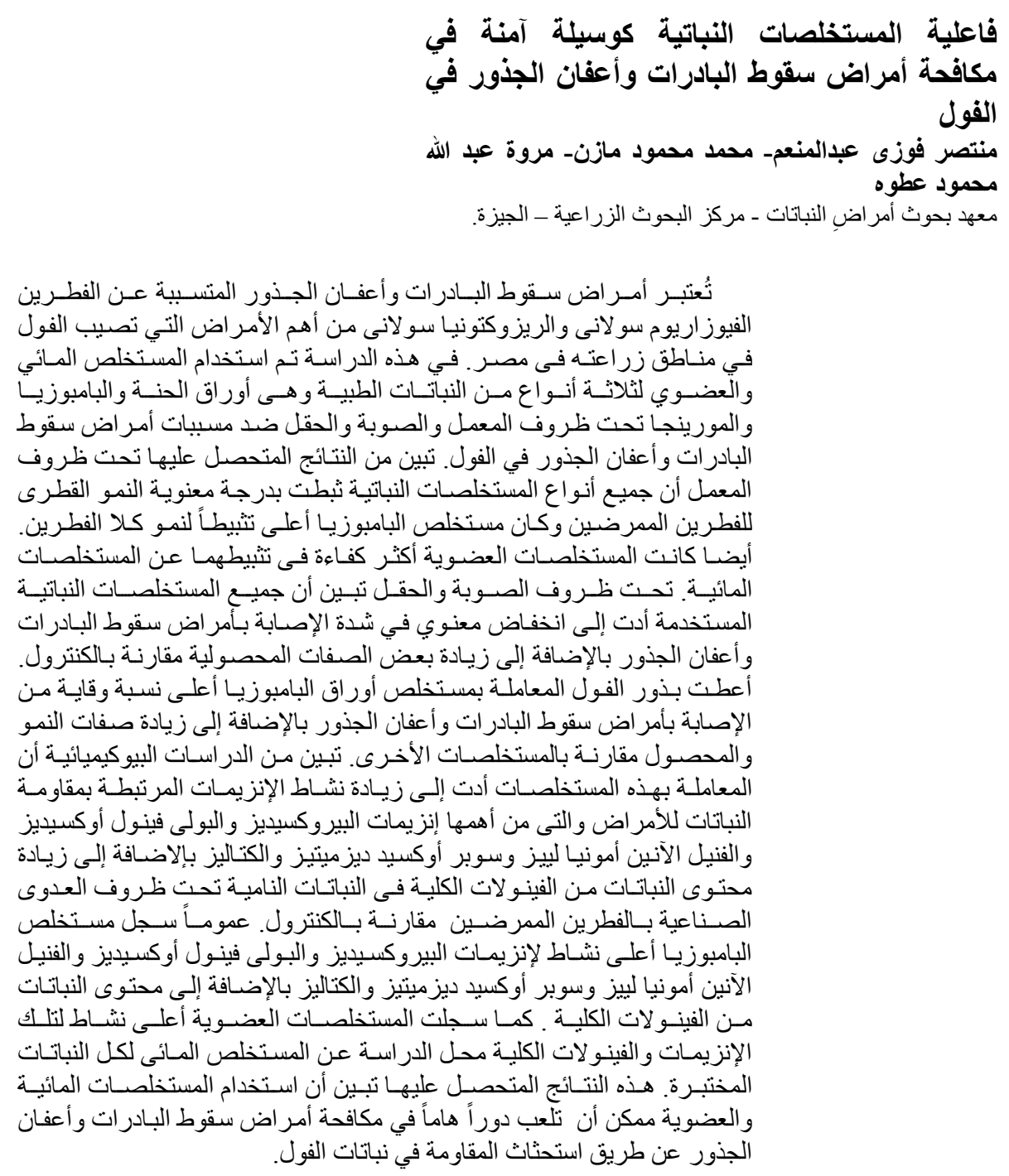